\title{
THE ELEMENTS OF GENDER EQUALITY IN THE LAW OF ANCIENT STATES: AN HISTORICAL-LEGAL ANALYSIS
}

\author{
Bysaga Yu. Yu.
}

\section{INTRODUCTION}

Gender equality is one of the main policy priorities of the European Union and our country. At the same time, according to the experts' analysis, not only in Ukraine but also in Europe, there are the elements of gender inequality and even manifestations of gender discrimination.

The principle of equality between men and women is enshrined in Article 24 of the Constitution of Ukraine, as well as in a number of international treaties, including: the UN Convention on the Elimination of All Forms of Discrimination against Women of 18 December $1979^{1}$, the conventions of the ILO: «The Convention on Equal Remuneration for Men and Women Workers for Work of Equal Value No. 100», dated June 29, $1951^{2}$, «The Convention on Maternity Protection (revised in 1952), No. 103», June 28, $1952^{3}$, and «The Convention concerning Discrimination in Respect of Employment and Occupation No. 111», June 24, 1975 ${ }^{4}$, «The Convention on Equal Opportunities and Equal Treatment for Men and Women Workers: Workers with Family Responsibilities No. 156» ${ }^{5}$, Council of Europe Convention on Preventing and Combating Violence against Women and Domestic Violence of 11 May 2011 ${ }^{6}$, the Charter of Fundamental Rights of the European Union of 7 December $2000^{7}$, Recommendation No. Rec (2003) 3 of Council of Europe Committee of Ministers to the Member States «On the Balanced Participation of Women and Men in

\footnotetext{
${ }^{1}$ Конвенція ООН про ліквідацію всіх форм дискримінації щодо жінок від 18.12.1979. URL: https://zakon.rada.gov.ua/laws/show/995_207.

${ }^{2}$ Конвенція про рівне винагородження чоловіків і жінок за працю рівної цінності № 100 від 29 червня 1951 p. URL: https://zakon3.rada.gov.ua/laws/show/993_002.

${ }^{3}$ Конвенція про охорону материнства (переглянута в 1952 році) N 103 від 28.06.1952. URL: https://zakon.rada.gov.ua/laws/show/993_122.

4 Конвенція про дискримінацію в галузі праці та занять N 111 від 24.06.1975. URL: https://zakon5.rada.gov.ua/laws/show/993_161.

5 Конвенція про рівне ставлення й рівні можливості для трудящих чоловіків i жінок: трудящі із сімейними обов’язками № 156 від 23 червня 1981 p. URL: https://zakon.rada.gov.ua/laws/main/993_010.

${ }^{6}$ Конвенція Ради Європи про запобігання насильству стосовно жінок і домашньому насильству та боротьбу з цими явищами від 11 травня 2011 p. URL: https://rm.coe.int/ $1680096 \mathrm{e} 45$.

${ }^{7}$ Хартія основних прав Європейського Союзу від 07.12.2000. URL: https://zakon.rada.gov.ua/cgi-bin/laws/main.cgi?nreg=994_524.
} 
Political and Social Decision-Making» of 12 March $2003^{8}$, etc. In Ukraine, a special Law «On Ensuring Equal Rights and Opportunities for Women and Men» ${ }^{9}$ was also adopted to guarantee the principle of gender equality.

Taking into consideration the fact that Roman traditions are preserved in EU law and Ukrainian law, there arises the question whether there were the elements of gender equality in the law of the Ancient States. It should be noted that scholars often refer to Aristotle quote: "A woman is a woman because she lacks masculine qualities. A woman suffers from the inferiority complex». Demosthenes wrote: «There are women-slaves who are to provide us with daily care and wives - to give us legitimate children and guard our families».

At the same time, A.V. Hrubinko notes that elements of gender equality are found in the law of Babylon and Ancient Egypt ${ }^{10}$. That is why it is particularly important to clarify the issue of the existence of gender equality elements in the law of the Ancient States.

\section{Gender Equality and the Law of Ancient Rome}

Exploring the rights of spouses under Roman law, M. V. Mendzhul distinguishes two types of marriage from the perspective of the rights of men and women: cum manu (dominated by the power of the man) and sine manu (without the power of the man). What concerns de facto actual cohabitation (concubinage), it did not give rise to rights such as legal marriage. Slaves did not have the right to enter into an official marriage. The frequent practice was that the owners allowed the slaves to become couples, but a child born by a slave woman from another slave or a citizen of Rome was also a slave ${ }^{11}$.

In marriage, cum manu, the woman was subordinate to her husband, and the property she purchased also belonged to the man who disposed of it freely. The husband was able to punish his wife, even sell her into slavery ${ }^{12}$.

Some scholars believe that Roman culture was masculine in nature and recognized the primary purpose of women in raising children. In the history

${ }^{8}$ Рекомендація № Rec (2003) 3 Комітету міністрів Ради Європи державам-членам «Про збалансоване представництво жінок і чоловіків у процесі прийняття політичних та громадських рішень» від 12 березня 2003 p. URL: https://zakon1.rada.gov.ua/ cgi-bin/laws/main.cgi?nreg=994_661.

${ }^{9}$ Про забезпечення рівних прав та можливостей жінок і чоловіків: Закон України від 08.09.2005, № 2866-IV. URL: https://zakon2.rada.gov.ua/laws/show/2866-15.

${ }^{10}$ Грубінко А.В. Права жінок у філософсько-правовій думці і практиці: зарубіжний та вітчизняний досвід. Форум права. 2013. № 1. С. 221.

${ }^{11}$ Менджул М. В. Права подружжя в римському приватному праві. Правова держава: історія, сучасність та перспективи формування в Україні: Матеріали міжнародної науково-практичної конференції, м. Ужгород, 15-16 лютого 2019 р. Ужгород: Ужгородський національний університет, 2019. С. 52.

12 Лещенко В.С., Разінкова А.В. Римські та сучасні українські особисті, майнові відносини подружжя (порівняльний аналіз). Актуальні проблеми держави і права. URL: http://www.apdp.in.ua/v41/17.pdf 99.

56 
of the development of Roman private law, there are examples of legislative restrictions on the inheritance rights of women. Indeed, in 169 BC. There was adopted Voconia's law, which forbade women, except the vestals (priestesses of the goddess Vesta), to be appointed the heirs of those citizens whose inheritance exceeded 100,000 sesterces $^{13}$.

The elements of equality were in marriage without the man's power (sine manu). In particular, the husband could not punish his wife or sell her into slavery. In such a marriage, a woman was able to stay a night outside home three times a year, but she had to respect her husband, obey him, and follow her husband if he changed his place of residence. If the woman did not perform her duties, this was the reason for the divorce. The husband had the right to demand the return of his wife from her father, was her legal representative.

During the reign of Emperor Constantine (306-337), the tradition of concluding donation agreements between the bride and the bridegroom became widespread. During the reign of Emperor Justinian (527-565), donating was allowed during marriage. During the marriage, the marriage donation was owned by the woman. If the marriage was terminated because of the woman, she passed the dowry to the husband and could not require the transfer of donatio ${ }^{14}$.

Augustus's Law on Marriage (lex Julia de maritandis ordinibus) established that men (ages 25 to 60) and women (aged 20 to 50) had to marry, and the breach of the law led to the responsibility in the form of forbidding them to bequeath their property as well as paying by them the tax in the amount of $1 \%$ of the value of the property.

In the times of Augustus, adultery was considered a crime. In the case of convicting a woman for adultery, she lost half the dowry and could be deported. If a man murdered his wife for adultery was considered a mitigating circumstance ${ }^{15}$.

${ }^{13}$ Вовк В.М. «Жіноче питання» у римському праві. Науковий вісник Львівського державного університету внутрішніх справ. Серія юридична. 2008. № 3. С. 1-9. URL: http://www2.lvduvs.edu.ua/documents_pdf/visnyky/nvsy/03_2008/08vvmurp.pdf.

14 Калюжний Р.А., Вовк В.М. Римське приватне право: підруч.для вищ.навчзакл. Київ, 2014. С. 127-128.

${ }^{15}$ Steven Fife. Augustus' Political, Social, \& Moral Reforms. URL: https://www.ancient.eu/ article/116/augustus-political-social--moral-reforms/. 


\section{The Elements of Equality between Men and Women in the Law of Ancient Greece}

In ancient Greece, as scholars state, the position of women was ambiguous. In Athens, she was under the authority of her father (and after marriage - her husband), but in Sparta women and men had almost the same status ${ }^{16}$.

Women in Ancient Athens had no right to own property other than their own clothing, jewelry and slave, and they could not enter into contracts. All financial issues were resolved by the husband (father, husband or closest relative through the male line). The woman was subjected to the guardianship of her father, and after marriage, her husband.

In contrast to Rome, in Athens, the guardianship of women in matters of money was real and unconditional. Everything the Athenian woman owned belonged to her guardian, and he could freely dispose of the property at his own discretion. However, he was responsible for ensuring that she had everything she needed for life (food, clothing, shelter, etc.).

Even in the matter of marriage, it was the father who chose the husband for his daughter, and discussed the size of the dowry. Accordingly, women with a big dowry married wealthy men, and conversely, without a dowry married a poor man. Unfortunately, when choosing a future husband, the father was usually guided by his own vision, and his interests in expanding property, the opportunity to earn extra money, establish contacts and political connections.

The traditional Athenian marriage was contracted in the presence of the witnesses, and it involved concluding an agreement on the value and size of the dowry. The age of men who were getting married for the first time was 20-30 years, and girls were aged only 14-15 years. Thus, marriages were overwhelmingly based not on feelings of mutual love. The need for early marriages for girls was explained by the erroneous, according to the modern understanding, medical rationale for a woman's physiological nature, and it was even considered necessary for their health.

Dowry had been an integral part of any marriage in Ancient Athens. The advantage of the dowry was that it could be used to support the household, to cover expenses, that is, it was a kind of contribution on the woman's side to meeting the needs of the family. Securing high dowries was a pledge of prestige in the community and a way to conclude a profitable and rewarding marriage for both parties. However, it was because of the need to provide a dowry that families preferred to have sons rather than daughters.

The dowry also provided the woman with some financial security in case of her husband's death or divorce, and it could be used if she decided to remarry. However, the thinkers and philosophers of that time noted that the

\footnotetext{
${ }^{16}$ Вікторія Гришко, Світлана Лівчук. Історичні передумови формування гендерної нерівності у суспільстві. Підприємництво, господарство і право. 2019. № 2 С. 141. 
dowry had to be abolished. For instance, Plato believed that the abolition of dowry was necessary because it would reduce the arrogance of women and weaken the enslavement of men ${ }^{17}$.

In the modern world, people are often critical of the dowry, and this situation is preserved in Muslim states, and this critical attitude is present at the level of traditions among some Slavic peoples.

Thus, the dowry was the wife's sole property, but it was managed by the husband who could spend it at his own discretion, without any restrictions. As a rule, the daughter did not receive land as the dowry, it was passed on to the sons.

In case of the husband's death or divorce, the value of the dowry belonged to the wife, but she could not dispose of it, the right to manage such property belonged to the father, her adult son or other relative through the male line. The guardian was to use the proceeds from the administration of the dowry for supporting the widowed wife, arranging a new marriage. After the woman's death the dowry was shared between her sons.

In ancient Greece, women were significantly restricted in their inheritance rights. After the man's death the property was distributed equally between his legitimate sons. If there were no sons, the daughters still had no right to inherit ${ }^{18}$. Over time, there had been worked out the norms according to which in case a man died and he had neither a son nor an adopted son, but only a daughter, it was she who temporarily inherited the property, but she did not have the ownership rights and this property was passed on to her future grandson (epikleros). If an Athenian woman died and did not give birth to a son, then her daughter passed on the property to her son's ownership, i. e. it became her grandson's property.

That is, women did not inherit the property, but rather became a means of transferring property to future descendants through the male line. The grandson acquired ownership of the property upon reaching the age of majority. Such a woman's husband had only the right to use the property of her deceased father.

Unlike in the situation with Athens, where a woman's status was clearly discriminatory compared to men, the elements of gender equality can be identified in Sparta.

Sparta consisted of three groups of people: citizens (they had political rights); free people (they were without any political rights); slaves (they had no rights and were the main labourers in most fields). In ancient Sparta, the ratio of slaves to citizens of the state was about 7 to 1 , and accordingly there was the threat of a possible uprising. There are historical facts which prove that in Sparta all children with disabilities were killed.

${ }^{17}$ James C. Thompson, B.A., M.Ed. WOMEN IN THE ANCIENT WORLD. The status, role and daily life of women in the ancient civilizations of Egypt, Rome, Athens, Israel and Babylonia, 2010. URL: http://www.womenintheancientworld.com/marriageinancientathens.htm.

${ }^{18}$ Ibid. 
The boys lived at home with their mother until the age of 7, then they left their dwelling and underwent military and sports training. The men married at about the age of 20, but they visited their wives on separate occasions and lived with other men in special facilities. Only as soon as they turned thirty did the Spartans stay the night at home, however, most of their time was spent in campaigns.

Just like in all of Greece, the main role of women was in the birth and upbringing of children. However, according to the Spartans, a woman was able to better fulfill her purpose if she was healthy. That is why physical education and athletics were as important for girls as they were for boys, and competitions were regularly held (running, wrestling, etc.).

The Spartan girls did not marry until they were eighteen. The house was run by a woman. Spartan women had a reputation all over the Greek world for their ability to run the family household ${ }^{19}$.

However, there was also somewhat negative practice when several brothers had one wife and their children from her were considered common in the family. This existed in order to prevent the division of their inheritance into several much smaller parts.

In the matter of inheritance, unlike in the situation with Athens, the Spartan women could inherit half of the property which was inherited by the sons, moreover, the land could be a part of the inheritance. Yet Aristotle also mentioned that women owned almost forty percent of the land in Sparta ${ }^{20}$.

Scientists justify, since men had been busy almost all day, these were women who, aiming to run the family household, concluded agreements, made purchases.

And there is no evidence that they needed their husbands' consent.

Thus, in Ancient Athens, a woman's legal position was clearly discriminatory, in particular, she could have only the limited property (clothing, jewelry, slaves), had no land ownership rights, could not enter into buying-selling contracts, was placed under the full guardianship of her father or husband. Athenian women did not have the right to choose a husband, it was done by her father and she married at an early age (14-15 years).

Unlike Athens where there was the apparent inequality in the legal status of men and women, it is in Sparta that one can find elements of gender equality. The girls received a good education, were involved in sports, intellectual development, married as soon as they reached at least the age of 18 , had inheritance rights, and they could even own land.

${ }^{19}$ James C. Thompson, B.A., M.Ed. WOMEN IN THE ANCIENT WORLD. The status, role and daily life of women in the ancient civilizations of Egypt, Rome, Athens, Israel and Babylonia, 2010. URL: http://www.womenintheancientworld.com/marriageinancientathens.htm.

20 Iveta Nikolājeva. Promocijas Darba Kopsavilkums Laulāto Mantisko Attiecību Institūta - PŪRA - Vēsturiskā Evolūcija Un Vieta Mūsdienu Kontinentālo Tiesību Saimē. Rīga, 2018. 29-31. URL: http://www.turiba.lv/f/2018/Kopsavilkums_Nikolajeva.pdf. 


\section{Gender Equality and the Law of Ancient Egypt}

Scholars emphasize that that the Ancient States are the cradle of all human culture: their emergence was the next stage in the history of mankind, reflecting the the transition from the primitive society to the state organization and the sustainable development which continues to this day ${ }^{21}$. We agree that civilizations of the Ancient World are rightly considered the cradle of the modern world, and Egypt played an important role.

Scholars stress that birth and marriage, as well as death in Egypt were marked by performing special rituals, and were believed to be big events in human life. Marriage was public and involved celebration. No evidence has been provided by scholars in relation to the fact whether dowry practice was widespread in Egypt.

In Ancient Egypt men got married, on average, at the age of 20, and girls - at the age of 15 . Analyzing the description of the scene where Ramses II is getting married, - «And then his Majesty saw how beautiful her face was and she seemed like a goddess to him. This was a great, mysterious, miraculous activity», scholars come to the conclusion that the celebration of marriage included a certain ceremony.

There are no reliable data as to whether permission to marry was required. Scholars substantiate that such permission was required for the marriage of slaves. However, given the early marriage age of girls, it is likely that the choice of the future husband was influenced by the parents. Admittedly, the situation whether the girl had the right to disagree with her father's choice and deny him during the period of the Old, Middle and New Kingdoms is not completely clear. Since the reign of Amasis XXVI the marriage required the consent of the future spouses, and the parents already played an auxiliary role in the procedure of concluding marriage. During the Ptolemaic period, when Greek and Egyptian laws existed side by side, scholars identify documents in which women with obviously Greek names married with the permission of the guardian, but Egyptian women entered into marriage without it, i. e. at their own will.

Scholars point out that there could be concluded marriage contracts, which were frequently used and made in writing. They assume that there were two types of contracts. According to the first type, the man transferred a certain amount of money and the woman became his wife. Such a kind of «payment for the bride» symbolized the seriousness of the intentions. The payment varied from low to high. If a woman decided to divorce her husband, then the money was paid to him. If the husband wanted to divorce his wife, he had to pay the fine in the same amount. Despite the fact that the payments were large, it was not a significant deterrent to prevent divorce.

\footnotetext{
${ }^{21}$ Свген Ланюк. Діалогічність політики і естетики у світоглядній парадигмі цивілізацій Стародавньго Сходу. Вісник Львівського університету. Серія філос.політолог. студії. 2014. Випуск 5. С. 230.
} 
In the second type of contract, since the husband acquired dowry, the procedure for supporting the future wife was clearly described (there was indicated the amount of money the husband had to spend on food and clothing, and a place of residence was guaranteed). With this type of contract the woman could demand divorce at any time. However, adultery was strictly forbidden and severely punished.

According to Egyptian law, in order to complete the transfer of property under a marriage contract, the husband had to assure that he had not sold or given his wealth to anyone else, and the document stated in writing that the husband no longer had the rights to the property.

Marriage contracts consistently contained a list of "woman's goods» which the wife brought with her to the family home. These items were usually of personal nature (clothing, jewelry, crockery, household items). Each item was priced and the husband promised to return it or its cost in case of divorce.

Some marriage contracts even contained the provision that obliged the husband, in case of his death, to distribute part or all of his property in some way. Scholars provide as an example the following fragments from the marriage contracts: «you are a part of my children, already born and who will be born, to have a part in everything that I own, and that I will receive»; «The children that you will give birth to for me are like my own children, and they, just as mine, possess everything I own and that I will receive»; «one-third of everything I own and I shall get, belongs to you and it will be given to the children you will give birth to for me»; «The children you will give birth to are the masters of all that I have and that I will receive».

Hence, even if something under the marriage contract had to belong to the wife, such acquisition of ownership was due to a special condition - the birth of children.

The analysis of the contracts gives grounds to conclude that they were much more restrictive of the rights of the husband than of the wife. Even without the contract, women were legally allowed to leave their dwelling at any time they wanted, and could take their personal belongings with them freely. The wife could relinquish her right to inheritance, and it could happen with or without the contract and, certainly, so that she could not leave the family at her own will without having the new place of residence.

Thus, the marriage contract restricted the rights and freedom of men and contained guarantees for women. Without a marriage contract, the husband could divorce his wife without any restrictions or property consequences, and accordingly marry someone else. It is thought that Egyptian law required men to support divorced wives until they remarried, but there is no conclusive evidence. Many marriage contracts not only provided for continued support, but also required the husband to divide his property between the children of his wife, even if he divorced her. 
Unfortunately, there is no information that would explain why in one case the marriage contract gave the husband the right to divorce his wife without financial charge, and in other cases there was set the obligation to share everything the husband obtained up to the wedding day. and everything that could be obtained with his children and his ex-wife. It should also be noted that many of the remaining contracts were signed many years after the wedding and even after the birth of the children. Therefore, it is quite justifiable to conclude that the marriage contract was a means of settling property relations and the husband's duty to maintain his wife in case of divorce or after his death.

In ancient Egypt, each of the spouses was free to initiate the procedure of dissolution of marriage, and the reasons, if any, for the dissolution of marriage were not relevant. Scholars note that written divorce agreements could be concluded as well. If a woman wanted to get married again, she had to show such a document to her future husband before he allowed her to move to him.

Divorce was simple enough, but the division of property was a real problem. The former wife had the right to take her personal belongings with her - clothing, jewelry, kitchenware, etc. - and, of course, married women's separate rights of ownership of the land, buildings, slaves they owned before marriage, were always preserved ${ }^{22}$.

It is well known that the Egyptian kings could and did have many wives, and that they married their sisters. It is also suggested that the marriage of brothers and sisters was a way for the Pharaohs to imitate gods and goddesses and distance themselves from the rest of the population. The ancient Egyptians believed that their Pharaoh was a god and he did not look like an ordinary person. Therefore, it is quite possible that marriage to a sister was seen as a way to increase the amount of royal blood in the next heir.

All the wives held the title of «the royal wives», but only the «the Great Wife» had the advantage of attending special ceremonies, and it was her son who was the first to inherit the throne. There were exceptions, for example, King Amonotep III had two «great wives» who participated in all the ceremonies simultaneously. Likewise, the titles of the royal sister and daughter of the king were of great importance in society.

The Egyptian kings gladly welcomed foreign brides aiming to establish diplomatic and economic ties, but refused to send their own daughters in return. One foreign monarch invited Pharaoh to send any beautiful woman he wanted if he simply said that she was a princess, because no one would know the difference. Pharaoh refused to even respond to the proposed compromise.

${ }^{22}$ James C. Thompson, B.A., M.Ed. WOMEN IN THE ANCIENT WORLD. The status, role and daily life of women in the ancient civilizations of Egypt, Rome, Athens, Israel and Babylonia, 2010. URL: http://www.womenintheancientworld.com/marriageinancientathens.htm. 
It is worth noting that there were no legal restrictions on the economic activities of women in ancient Egypt. Most contracts and business papers found by scientists are the ones where men acted as a party, but there are enough legal documents of all types in which women act as a party. This shows that their rights were more than merely theoretical. Women could and did own property, bought and sold it, borrowed and lent it, they acted as a party in lawsuits, had the right to make a will and inherit property.

Undoubtedly, most Egyptians were quite poor, and accordingly, for many, their property included only their daily earnings. Therefore, quite often the widows were needy and lived in poverty.

The upbringing of children and housekeeping were the main sphere of occupation for women in Egypt. However, women could also serve the gods, that is, they were priests. There are also cases when they ruled the country, for example, Queen Hatshepsut. To become the ruler of a nomus, or even a pharaoh, it was not necessary to be the son of a ruler. It was frequently enough to just marry a daughter of a nomarch or pharaoh, and many ambitious young men from aristocratic families did so. The fact is that the title and property of the ruler were inherited equally by sons and daughters, and sometimes to a greater extent, by daughters. This is due to the fact that the ancient Egyptians traced their lineage through the maternal line, believing that the origin of children can be reliably proven only on the side of the mother who gave birth to them ${ }^{23}$.

The status of women underwent changes depending on the historical period. In the Old and Middle Kingdoms, the royal wife had first of all to give birth to as many offspring - sons, as possible, to ensure the smooth functioning of the palace, to be regent if her husband died until the son was able to rule on his own, to provide tacit support to the husband in all things. In the New Kingdom, the Queen became much more prominent and powerful. She held secular and religious titles behind which there were real responsibilities, she had estates and the land, slaves and property managers. Similarly, if a child became a Pharaoh, then his mother (probably the Great Wife of the previous monarch) could become regent. This has happened several times in the history of Egypt, and in particular the mentioned example with Hatshepsut also confirms this. However, after having fulfilled her duties as a ruler on behalf of her son for several years, she simply renounced the regency and began calling herself the female Horus, a legitimate Pharaoh, and ruled as a full king to death.

There are also examples of child marriages. In the New Kingdom, Tutankhamun ascended the throne at the age of eight (by some sources nine). Undoubtedly, to be able to rule he needed experienced advisers, but there

23 Мартинюк А.В. Правове становище жінок у Стародавньому Сгипті. Історія цивілізацій стародавності та середньовіччя. 2015. С. 83-84. 
was no regency. Therefore, Tutankhamun had to marry Anhesenamun immediately, although Egypt had had no history of child marriage before. However, scholars do not really know who Tutankhamun's mother was, and it is possible that she died before he ascended the throne, so it was not possible to establish a regency.

We have already emphasized that women in ancient Egypt had the same rights and responsibilities as men when it came to owning and managing property, and they regularly attended social events with their husbands. It was more than just a formality, and the Athenians did not understand Egyptian women's freedom.

The question rises how a woman in Ancient Egypt could receive some income. For example, some kept vegetable gardens, many made clothes. There is the document by which the woman buys a slave. She pays half, while borrowing the other part of money. Women's slaves were hired. There is the receipt according to which one woman received some clothing, a bull and sixteen goats as payment for 27 days of her slave's work. There were cases when women bought one slave together.

Women had the right to inherit and manage significant property. In most cases, doubtlessly, a clerical representative was hired to manage the property. There were few opportunities for a woman to get paid outside the domestic sphere. If she inherited a three- to five-acre plot of land (typical of the independent peasantry), she still needed male support to cultivate the land.

In Egypt daughters could receive the inheritance equally with their brothers. There have been identified testaments which indicate that the inheritance had to pass to certain children, not the others. Women also had the right to prepare their will and transmit the property at thier own discretion. There are examples of the papers in which the husband and the wife distributed their family assets between children in different ways. However, most people did not write their wills and their property was distributed equally among all children, that is, sons and daughters.

In addition, according to the laws of Egypt, the heir was obliged to provide for the burial of the person who left the inheritance, the wife had to receive a third of her husband's property, and after the death of the wife, her third had to be shared equally between the children. The inherited property, if there was no will, was divided equally between all heirs (children).

Thus, unlike in most other civilizations of the Ancient World, the law in Egypt did not contain such an unequal treatment of men and women. The theory and practice, of course, did not always go hand in hand, and there is the evidence proving that in many homes these were men who ran the family household. Although the prevailing rights both in the family and in other fields belonged predominantly to men, in the Old Kingdom there were cases when a woman ruled. Women played an important role in Egypt's politics, 
and they were treated with respect, because the Pharaohs were born by their mothers, and they had a particularly respectful attitude towards them. Royal women had always played an important role in many public ceremonies, it is especially notable since the times of Nefertiti.

The ancient Egyptian marriage required the permission of their parents, at least before the reign of the Twenty-sixth Dynasty. Marriages between siblings were common. For the most part, marriages were monogamous, they were concluded mostly within the same social class.

Men's and women's certain ownership rights to any property that was theirs before marriage preserved. Each of the parties could initiate the divorce, moreover, no valid reason was required. The wife was usually entitled to one third of her husband's property after his death. Additionally, men and women tended to divide their property among their children.

\section{CONCLUSIONS}

Thus, gender equality is not the achievement of the $21^{\text {st }}$ or $21^{\text {st }}$ centuries, but the result of a thousand-year history of promoting equal rights for women and men. At present, gender equality is determined as the pivotal principle at the national level (in Article 24 of the Constitution of Ukraine, the Law of Ukraine "On Ensuring Equal Rights and Opportunities for Women and Men»), at the European level (Council of Europe Convention on Preventing and Combating Violence against Women and Domestic Violence of 11 May 2011, the Charter of Fundamental Rights of the European Union of 7 December 2000, Recommendation No. Rec (2003) 3 of Council of Europe Committee of Ministers to the Member States «On the Balanced Participation of Women and Men in Political and Social Decision-Making» of 12 March 2003, etc.) and at the international level (the UN Convention on the Elimination of All Forms of Discrimination against Women of 18 December 1979, the conventions of the ILO: «The Convention on Equal Remuneration for Men and Women Workers for Work of Equal Value No. 100», dated June 29, 1951, «The Convention concerning Discrimination in Respect of Employment and Occupation No. 111» of June 24, 1975 , «The Convention on Equal Opportunities and Equal Treatment for Men and Women Workers: Workers with Family Responsibilities No. 156», etc.).

However, the historical background and elements of gender equality in the have also been identified by us in the law of the Ancient States. It is common knowledge that Roman culture was musculine in nature and recognized the primary purpose of women in raising children. In the history of the development of Roman private law, there are examples of legislative restrictions on women's inheritance rights. However, the elements of equality were present in marriages without a man's power (sine manu). 
In ancient Greece, women's situation was ambiguous. In Athens inequality was evident and even discrimination against women prevailed whereas in Sparta women and men had almost equal rights. In particular, in Athens, women could only have limited rights to property (clothing, jewelry, slaves), had no land ownership rights, could not conclude buy-sell contracts, were under the full guardianship of their father or husband.

In comparison with Athens, in Sparta one can identify the elements of gender equality. The girls received a good education, were involved in sports, intellectual development, married from the age of 18, had inheritance rights, and could even own land.

In contrast to ancient Rome and Athens, the law in Egypt did not feature such an unequal treatment of men and women. In spite of the fact that the prevailing rights in the family as well as in other fields belonged mainly to men, in the Old Kingdom there were cases when there ruled a woman. Men and women retained separate ownership rights to any property that was theirs before marriage, they could freely enter into contracts. Each of the parties could initiate the divorce, and no substantial reason was required. The wife was usually entitled to one third of her husband's property after his death. In addition, men and women were free to execute their wills.

\section{SUMMARY}

The study addresses the pressing issue of finding out the preconditions and origins of gender equality in the law of the Ancient States. The study examines the rights and responsibilities of men and women in Ancient Rome, Athens, Sparta and Egypt.

It was established that under Roman law there were two types of marriage: cum manu (the power of the husband dominates) and sine manu (without the power of the husband). De facto actual cohabitation (concubinage) did not give rise to the rights such as legal marriage. In marriage, cum manu, the woman was subordinate to her husband, and the property she had purchased herself also belonged to the husband who managed it freely.

The husband could punish his wife, even sell her into slavery. The elements of equality were present in marriage without the power of a man (sine manu). In such a marriage, a woman could stay home three times a year, but she had to respect her husband, obey him, and follow her husband if he changed his place of residence. If the woman did not perform her duties, it was the reason for the divorce.

The elements of equality were present in marriage without the man's power (sine manu). In such a marriage, a woman was able to stay a night outside home three times a year, but she had to respect her husband, obey him, and follow her husband if he changed his place of living. If the woman did not carry out her duties, this was the ground of divorce. 
It has been revealed that in Ancient Greece the status of a woman was ambiguous, if in Athens she was under the authority of her father (and after marriage - her husband), then in Sparta there were the elements of gender equality. It has been found out that women in Ancient Athens had no right to own property other than their own clothing, jewelry and slave, could not enter into contracts. All financial issues were resolved by the husband (father or a closest relative in the male line). The woman was under her parents' full guardianship, and after marriage - her husband', and was significantly restricted in her inheritance rights.

In comparison with Athens, in Sparta one can identify the elements of gender equality. Particularly, the girls received a good education, were involved in sports, intellectual development, married from the age of 18, had inheritance rights, and could even own land.

The study of the legal status of women in Ancient Egypt has turned out especially valuable. It has been found out that there were no legal restrictions on the economic activities of women in Ancient Egypt. Women could and possessed property, bought and sold, borrowed and lent, were parties involved in lawsuits, had the right to make a will and inherit property. Moreover, it is in the ancient history of Egypt that there are examples of a woman ruling the country. Both the man and the woman could initiate divorce without any valid reason. The wife was usually entitled to one third of her husband's property after his death. What's more, men and women were free to draw up their wills.

\section{REFERENCES}

1. Конвенція ООН про ліквідацію всіх форм дискримінації щодо жінок від 18.12.1979. URL: https://zakon.rada.gov.ua/laws/show/995_207.

2. Конвенція про рівне винагородження чоловіків і жінок за працю рівної цінності № 100 від 29 червня 1951 p. URL: https://zakon3.rada.gov.ua/ laws/show/993_002.

3. Конвенція про охорону материнства (переглянута в 1952 році) № 103 від 28.06.1952. URL: https://zakon.rada.gov.ua/laws/show/993_122.

4. Конвенція про дискримінацію в галузі праці та занять № 111 від 24.06.1975. URL: https://zakon5.rada.gov.ua/laws/show/993_161.

5. Конвенція про рівне ставлення й рівні можливості для трудящих чоловіків і жінок: трудящі із сімейними обов'язками № 156 від 23 червня 1981 p. URL: https://zakon.rada.gov.ua/laws/main/993_010.

6. Конвенція Ради Свропи про запобігання насильству стосовно жінок і домашньому насильству та боротьбу з цими явищами від 11 травня 2011 p. URL: https://rm.coe.int/1680096e45

7. Хартія основних прав Європейського Союзу від 07.12.2000. URL: https://zakon.rada.gov.ua/cgi-bin/laws/main.cgi?nreg=994_524. 
8. Рекомендація № Rec (2003) 3 Комітету міністрів Ради Європи державам-членам «Про збалансоване представництво жінок і чоловіків у процесі прийняття політичних та громадських рішень» від 12 березня 2003 p. URL: https://zakon1.rada.gov.ua/cgi-bin/laws/main.cgi?nreg= 994_661.

9. Про забезпечення рівних прав та можливостей жінок і чоловіків: Закон України від 08.09.2005, № 2866-IV. URL: https://zakon2.rada.gov.ua/ laws/show/2866-15.

10. Грубінко А.В. Права жінок у філософсько-правовій думці і практиці: зарубіжний та вітчизняний досвід. Форум права. 2013. № 1. C. 221-228.

11. Менджул М. В. Права подружжя в римському приватному праві. Правова держава: історія, сучасність та перспективи формування в Україні: Матеріали міжнародної науково-практичної конференції, м. Ужгород, 15-16 лютого 2019 р. Ужгород: Ужгородський національний університет, 2019. С. 52-55.

12. Лещенко В.С., Разінкова А.В. Римські та сучасні українські особисті, майнові відносини подружжя (порівняльний аналіз). Актуальні проблеми держави i права. C. 98-104. URL: http://www.apdp.in.ua/ v41/17.pdf.

13. Вовк В.М. «Жіноче питання» у римському праві. Науковий вісник Львівського державного університету внутрішніх справ. Серія юридична. 2008. № 3. C. 1-9. URL: http://www2.lvduvs.edu.ua/ documents_pdf/visnyky/nvsy/03_2008/08vvmurp.pdf.

14. Калюжний Р.А., Вовк В.М. Римське приватне право: підруч. для вищ.навчзакл. Київ, 2014. 240 с.

15. Steven Fife. Augustus' Political, Social, \& Moral Reforms. URL: https://www.ancient.eu/article/116/augustus-political-social--moral-reforms/

16. Вікторія Гришко, Світлана Лівчук. Історичні передумови формування гендерної нерівності у суспільстві. Підприємництво, господарство і право. 2019. № 2. С. 141-145.

17. James C. Thompson, B.A., M.Ed. Women in the ancient world. The status, role and daily life of women in the ancient civilizations of Egypt, Rome, Athens, Israel and Babylonia, 2010. URL: http://www.womenintheancientworld.com/marriageinancientathens.htm.

18. Iveta Nikolājeva . Promocijas Darba Kopsavilkums Laulāto Mantisko Attiecību Institūta - PŪRA - Vēsturiskā Evolūcija Un Vieta Mūsdienu Kontinentālo Tiesību Saimē. Rīga, 2018. 29-31. URL: http://www.turiba.lv/ f/2018/Kopsavilkums_Nikolajeva.pdf.

19. Свген Ланюк. Діалогічність політики і естетики у світоглядній парадигмі цивілізацій Стародавньго Сходу. Вісник Львівського університету. Серія філос.-політолог. студії. 2014. Випуск 5. C. $230-240$. 
20. Мартинюк А.В. Правове становище жінок у Стародавньому Єгипті. Історія цивілізацій стародавності та середньовіччя. 2015. C. 83-86.

Information about the author: Bysaga Yu. Yu.,

Candidate of Law Sciences, Associate Professor, Department of Administrative, Financial and Information Law, Faculty of Law, Uzhhorod National University 26, Kapitulna str., Uzhhorod, 88000, Ukraine 